\title{
The Analysis of Government Intervention and Stock Market during Crises Periods
}

\author{
Fiesty Utami ${ }^{\mathrm{a}^{*}}$ and $\mathrm{Ai}-\mathrm{Chi} \mathrm{Hsu}^{\mathrm{b}}$ \\ ${ }^{a}$ Lecturer, Departement of Accounting, Politeknik Negeri Bandung, Indonesia \\ ${ }^{\mathrm{b}}$ Associate Professor, Department of Finance, National Yunlin University of Science and Technology, \\ Taiwan
}

Received 15 October 2018; accepted 03 January 2019

\begin{abstract}
The government, through central banks, has a monetary authority to do an intervention, either directly or indirectly. Central banks do a direct intervention by exchanging reserves to influence the exchange rate and do an indirect intervention by increasing or decreasing the interest rate. However, when the currency crises happen, smoothing the currency movements by doing government intervention may reduce fears in the financial markets. This study examines the government intervention effect in 27 countries on the stock market during the crises periods, either during the Asian currency crises or currency crises of each country. To estimate abnormal returns, this study uses the traditional market model. Then, in the lack of official government intervention data, this study uses the proxy of government intervention to estimate the intervention activities. This study shows that in currency crises periods, the govermuent interventions do not effectively impact exchange rate, stock price, and stock market return.
\end{abstract}

\section{KEYWORDS}

Exchange rate

Interest rate

Government intervention

Stock market

\section{INTRODUCTION}

Governments are the most important players in financial markets. Their actions will affect interest rates, money supply, inflation, aggregate output, and the amount of credit. Government implements monetary policy authority which is crucial to the health of the economy. One of the interesting monetary policy tools to control currency value is by engaging in international financial transactions called central bank intervention, or government intervention.

The government actively intervene the foreign exchange (forex) market in order to reduce the volatility and maintain the exchange rate. It engages in international financial transactions to do an intervention, also known as currency manipulation, by buying and selling currencies. This intervention will also influence the monetary funds' transfer rate of the country's currency. There are many intervention options in order to decrease the exchange rate volatility, viz. intervention 
against appreciation (Pontines \& Rajan, 2011), intervention against depreciation (Humpage, 1988), coordinated intervention (Dominguez, 1998), unilateral intervention, secret intervention (Beine \& Lecourt, 2004), and announced intervention. If a government wants to do an intervention in order to against depreciation, then it can buy (sell) foreign currencies in the forex market. When currency crises happen, the government can choose either to remain passive or to intervene. This intervention induces financial operation that changes the foreign exchange position. The government intervention accomplishment depends on how the government sterilizes the impact of its interventions, the timing, and the amount of interventions (Madura, 2013).

The result of previous researches which investigate the government intervention impact on the rate of exchange is rather mixed. In one view, intervention operations generally increase the volatility of exchange rate (Beine, Bénassy-Quéré, \& Lecourt, 2002; Dominguez, 1998; Inoue, 2015). Meanwhile, others argue that intervention operations affect the exchange rate level, and can also stop the speculative attacks against a currency, thereby the exchange rate level will decrease (Adler, Lisack, \& Mano, 2015; Aguilar \& Nydahl, 2000; Behera, Narasimhan, \& Murty, 2008; Pattanaik \& Sahoo, 2003). A previous study by Neely (2005) describes that the government intervention does not give a permanent effect on exchange rate volatility. However, the rate of exchange might be more volatile without intervention. Madura (2013) notes that in the absence of intervention, however, currency movements will be even more volatile.

Nowadays, government interventions are less to do in developed countries because they believe the government intervention is effective only in the short period of time. Moreover, the large scale of intervention will slowly weaken the stance of monetary policy. Meanwhile, private financial markets are strong enough to manage shocks. Government intervention could be risky to do because it can weaken the government credibility if the government fails in maintaining the exchange rate. However, developing countries sometimes still actively do the intervention because they believe that intervention will effectively control inflation, enhance competitiveness, and prevent currency crises, such as large appreciation/ appreciation swings.

Government intervention can affect the stock market through interest rates and exchange rates. When the government intervention effectively influences the level of exchange rate, it will influence the stock market as well. Practically, the research about government intervention and the stock market is limited. However, there is a study of Hartmann and Pierdzioch (2007) which finds that exchange rate movements have a nonlinear link with stock returns. The link becomes strong in the period of government interventions.

One of the outstanding studies is from Reboredo, Rivera-Castro, and Ugolini (2016) who find that depreciation (appreciation) of the domestic currency improves (deteriorates) the international competitiveness of cash flows and domestic firms, which then increases (reduces) the stock prices in the market. It can be said that there is a positive relation between the currency values and the stock prices in developing countries.

This study examines the stock market reaction around government interventions using an event study framework. It is similar to the researches of Glen (2002) and Patro, Wald, and Wu (2014). They use the traditional market model in order to estimate the abnormal returns, and it gives a result that there is a significant equity market decline before and after the devaluation announcement. Furthermore, the amount of the devaluation significantly affects the stock return.

There are some previous studies of Égert and Kočenda (2014) who estimate the nominal equilibrium rate of exchange and find that the responsiveness to government verbal interventions of the exchange rates becomes significant only during the crisis. The government can either start an 
intervention, which can be successful or unsuccessful, or abstain from the intervention (Erler, Bauer, \& Herz, 2015). Moreover, Erler et al. (2015) also find a relation between government interventions and macroeconomic variables in the currency crises periods. There is also another study which examines the government intervention and the financial market. Pennathur, Smith, and Subrahmanyam (2014) examine the reaction of the market in response to crisis between 2007 and 2009. They find that the interventions are risk-increasing and wealth-decreasing events for financial institutions.

Accordingly, with those previous studies, this study is interested in examining the government intervention during Asian currency crises and the currency crises period in each country itself. To prevent excessive exchange rate volatility in the short period of time, governments need to stabilize this volatility. The exchange rate uncertainty can decrease profits, which will make the investors pull out their money from the country which has exchange rate uncertainty, and the condition will be getting worse. This condition gives us a figure that exchange rate volatility can spill over into financial systems, which, in this study specifically, the stock market. However, the exchange rate will determine the stock prices, which means that the exchange rate volatility will give effect to stock market volatility. This statement is in-line with Reboredo et al. (2016) research result.

This research aims to analyses the government intervention effect on financial stability. More precisely, this study contributes to provide empirical results toward whether the government intervention can contribute to the stock market response.

\section{THEORETICAL FRAMEWORK AND HYPOTHESES}

\section{Government Intervention}

Central banks intervene in the forex (foreign exchange) market to maintain the exchange rate. They engage in international financial transactions to do an intervention, which is also known as currency manipulation, by buying and selling currencies. This intervention, like other monetary policy tools, will also influence the monetary funds' transfer rate of the country's currency.

The government does an intervention in order to control inflation and maintain financial stability as well as competitiveness (Bank for International Settlements, 2005). Madura (2014) states that the government manages the exchange rate to smooth the exchange rate volatility and to set up implicit exchange rate boundaries. In this way, some central banks attempt to maintain their home currency rates within the band.

The government event in this study encompasses direct and indirect intervention. Central bank as the monetary authority does a direct intervention by exchanging reserves in the forex market to influence the exchange rate. Government intervention can stimulate its country's economy by purchasing foreign currencies. Mishkin (2013) notes that a government's purchase of local currency and the sale of foreign currency will decrease the monetary base and International reserves. In this way, when the government purchases foreign currencies, the local currency weakens against the foreign currencies, which makes the country's exports increase and then increases the country's economic growth as well.

The government intervention effectiveness is based on the number of reserves the government can use. If the government just has a low level of reserves, it may not be able to give enough pressure 
to the foreign exchange market because the economic trouble faced by the country and the market forces will crash it (Madura, 2013). When a government increases its country's interest rates, it can reduce inflation in two ways. Firstly, it will strengthen its local currencies against foreign currencies and make the costs of import decreases, which forces the local firms to keep their price low. Secondly, financing costs to firms and individual will increase while the borrowing and spending will decrease, which will make the inflation decreases as well. Figure 1 portrays how the government intervention can reduce inflation.

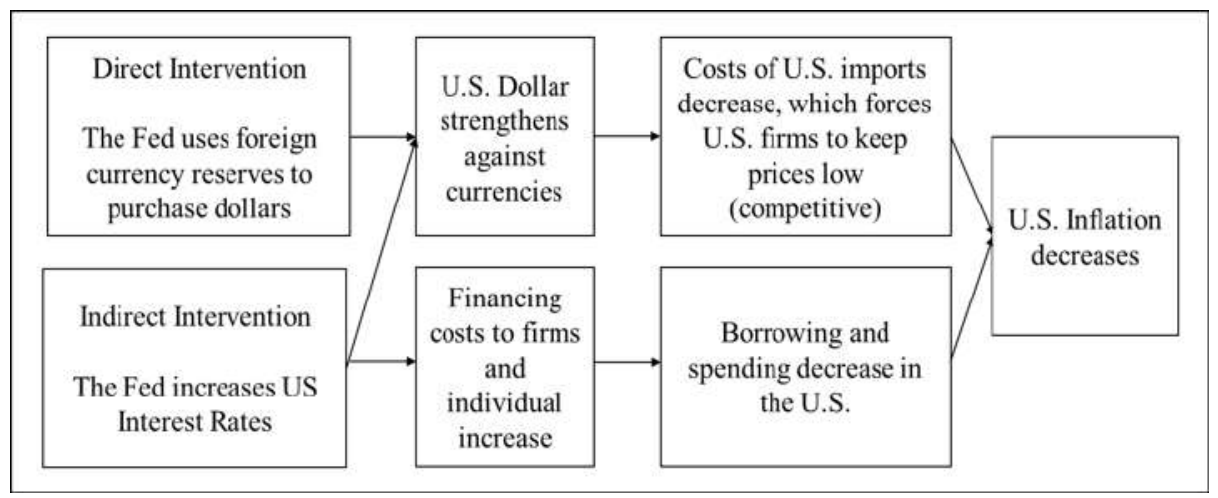

Figure 1. How intervention can reduce inflation (Source: Madura, 2013)

As in Asian crises, at that time the U.S. lowered its interest rates more than it would have without the crisis. Although there was some concerns that the lower rates would lead to higher U.S. inflation, a greater concern also arose that if rates were not lowered, the United States would experience a weak economy, which would be transmitted to other countries. The U.S. interest rates provided some stimulus to the U.S. economy, offsetting the reduction in U.S. economic growth due to lower demand for foreign exports. Thus, the Fed's monetary policy was not only influenced by international conditions but also had an influence on those conditions (Madura, 2002).

\section{Stock Market}

Financial markets are critical to promote greater economic efficiency by distributing funds. One of most popular financial markets is stock market, which almost every country has. Stocks are securities issued by companies as the issuers. A stock, a piece of paper that represents a share of ownership in a company, is traded on the Exchange Traded Fund (ETF). When investors buy a stock, they will become the owners or the shareholders of a company. It claims the earnings of the company (share of stock) based on how much equity the investors invested in that company.

\section{Currency Crises}

The currency crisis affects economic activity in many ways. It causes a large depreciation. If the government intervenes the market and the intervention does not succeed, the government will face the costs of stabilizing the market. However, if the government chooses not to do the intervention, the government may just face a small drop. Government intervention can affect the 
stock market through exchange rates and interest rates. When the government intervention effectively influences the exchange rate level, it will also influence the stock market.

The government is likely to focus on the interest rates when using indirect intervention. For example, when the government increases its interest rate, it will make the financing costs to firms and individual increases and the stock prices goes down. However, when the currency crises happen, smoothing the currency movements by doing government intervention may reduce fears in the financial markets.

This below discounted cash flow model calculation describes government intervention theory (changes of interest rates) on stock market return.

$$
P=\sum_{t=1}^{\infty} \frac{C F_{t}}{(1+R)^{t}}
$$

\footnotetext{
*Discounted Cash Flow Model

$\mathrm{P}$ : Theoretical Price of Stock

CF: Cash Flow to Equity

$\mathrm{R}$ : Discount Rate
}

Thus, following hypotheses on the association between government intervention and stock market during crises periods are formulated as follow:

$\mathrm{H}_{1}$ : There are significant abnormal returns around government intervention events during Asian currency crises.

$\mathrm{H}_{2}$ : There are significant abnormal returns around government intervention events during currency crises of each count.

\section{RESEARCH METHOD}

The method of data collection in this research is by using secondary data. The data are accessed from Datastream, IFS, OECD, and MSCI database. The sample of this study covers 27 countries. The criteria of the sample are: (1) the country must be listed on MSCI, (2) limit the sample to countries which provide International reserves and 3-month treasury rate, (3) the country must have done at least one intervention, based on the estimation that intervention index is significant when it exceeds the average value of the previous twelve months intervention index plus three times standard deviations, and (4) the country has done at least one government intervention; either in Asian crises periods or in its own currency crises.

In the absence of official government intervention data, the government's holdings changes of reserves can be a good proxy for detecting intervention (Wong, 2014). Adler et al. (2015) and Patro et al. (2014) investigate the government intervention by using reserves as the proxy for government intervention. Based on that, in this study, the researchers use the independent variable, the intervention index as the proxy of government intervention. The researchers follow the approach of the previous study by Erler et al. (2015) which calculates the intervention index based on the changes of interest rate and reserves. This study states that an intervention is significant if the intervention index is more than the average value of the previous twelve months intervention index plus three times standard deviations. 


$$
\text { INTX }=\frac{\Delta i_{t}}{\sigma \Delta i_{t}}-\frac{\Delta r_{t}}{\sigma \Delta r_{t}}
$$

The dependent variable in this research is the stock market return. This study uses event study analysis by using monthly returns on MSCI country indices which are denominated in USD. The stock market return is the return that is calculated from the stock price index by using this formula:

$$
\text { Stock Return }=\frac{\text { Ending Price-Initial Price }}{\text { Initial Price }} \times 100
$$

MacKinlay (1997) study indicates that the effect of an event will be reflected immediately in the stock price. Thus, a measure of the economic effect event can be constructed by using stock prices which are observed over a relatively short period. Event period means how long the intervention period will affect the company's share price before and after the occurrence of this event. The event period is $t-12$ through $t+12$. The estimation period is $t-24$ through $t-13$. The choice of the observation period refers to the method used by Patro et al., (2014) in investigating the effect of devaluation on the stock market response.

In this event study research, the event period is $t-12$ to $t+1$, whereas the estimation period is $\mathrm{t}-24$ to $\mathrm{t}-13$ (Patro et al., 2014), and the month of government intervention event is $\mathrm{t}=\mathrm{o}$. However, this study regresses the returns of each country to the returns of the market index with this market model formula:

$$
R_{i, t}=\alpha_{i}+\beta_{i} R_{m, t}+\varepsilon_{i, t}
$$

in which: $R_{i, t}$ is the monthly return of a country $i$ in time $t, \alpha_{i}$ is the alpha of stock $i$ estimated from pre-event measurement period, $\beta_{i}$ is the beta of stock $i$ estimated from pre-event measurement period, and $R_{m, t}$ is the return of the world market index.

This study calculates the abnormal return and cumulative abnormal return by using the parameters estimated from the market model. As pioneered by Fama and MacBeth (1973), the abnormal returns are calculated as follows:

$$
A R_{i, t}=R_{i, t}-\left[\widehat{\alpha}_{l}+\widehat{\beta}_{l} R_{m, t}\right]
$$

After computing the abnormal return, then this study computes the cumulative abnormal returns for each event. The Average Abnormal Return (AAR) and the Cumulative Average Abnormal Return (CAAR) are also calculated for each country and all countries. To get a sense of the accumulative effect of the abnormal returns, computing the CAARs is a good statistical analysis that can be used (Markus, 2003).

\section{RESULTS}

This study estimates abnormal returns around interventions by using the market model. The estimation period is from $t=-24$ to $t=-13$, where the month of government intervention event is 
$\mathrm{t}=\mathrm{o}$. This study tests the Average Abnormal Returns (AARs) whether the AARs are significantly different from zero or not. From the result of intervention proxy calculation, it is found that there are 44 government interventions during the currency crises present in 21 countries, and 27 interventions present in 24 countries during Asian currency crises (see Appendix A and B).

This study also analyses the stock market response by calculating the Cumulative Abnormal Returns (CARs). Appendix C presents the empirical result of CARs for country equity indices around government interventions in two kinds of panels. Panel A shows the CARs of the countries that did intervention in Asian crises periods and its significance based on t-statistic and z-statistic. Furthermore, Panel A displays the mean of CARs of each country and its significance based on tstatistic. Subsequently, in Appendix C -Panel B, it can be seen that this panel provides the CARs of some countries, which did intervention during currency crises periods happened in their own countries. This study analyses the CARs before, during, and after the interventions.

\section{Abnormal Returns Around Interventions During Asian Crisis (July 1997-1998)}

Asian Crisis in 1998 gave underlying shocks to the economy of Asian countries and significant spillover effects outside the region. This study estimates abnormal returns during Asian crises periods (27 interventions in 24 countries).

The findings in Panel A show that almost all the CARs are significantly negative around government intervention. The government intervention CARs for months $(-4,+4)$ is -25 percent, which is significant at t-stat of -3.53 and z-stat of 3.66. In fact, most of the CARs tested in the Asian currency crises periods are significantly negative at the 1 percent level using two statistical tests (t-stat and non-parametric sign test). These results show that on the average, the stock markets react negatively to government interventions during Asian crises. Also, an interesting fact of the Panel B, there are no significant abnormal returns in the parameter $(-5,-1)$ and $(-2,-$ 1). However, it can be said that the stock market does not anticipate the government intervention during Asian crises and intervention events are often undertaken when the stock markets are normal.

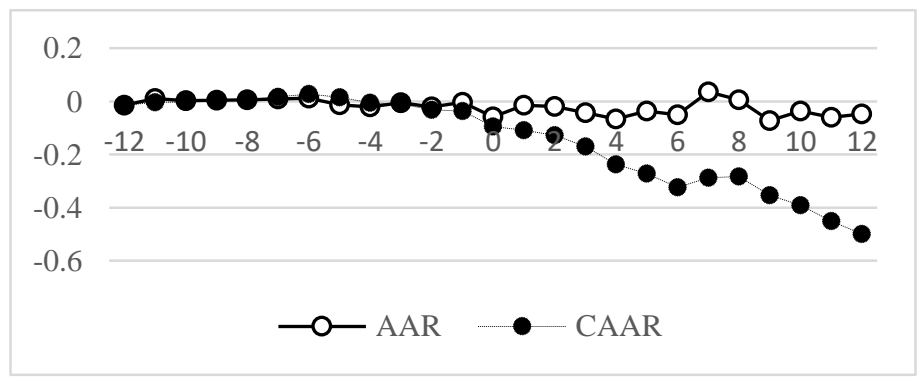

Figure 2. AAR and CAAR around the government interventions during Asian crises

Figure 2 presents graphically the results for the AARs and CAARs. The patterns of the CAARs confirm the negative impact of government intervention on country index returns. Moreover, the patterns show negative abnormal returns before the government intervention. It can also be seen that after the government intervention, the stock market response is more decreasing. 


\section{Abnormal Returns Around Interventions during Currency Crises Periods of Each Country}

This study also examines the currency crises periods of each country. The currency crises periods data of each country are taken from Reinhart and Rogoff (2011) and Laeven and Valencia (2018) data. From the result of intervention proxy calculation, it is found that there are 44 government interventions during the currency crisis present in 21 countries.

The CARs in Appendix C Panel B for months $(-1,+1),-8$ percent, are significantly negative at the five percent level using t-stat and z-stat. Furthermore, the CARs for months $(-1,+3),-12$ percent, are significantly different from zero at the 5 percent level using t-stat and 1 percent level using z-stat. These results indicate that the stock market reacts negatively to government intervention.

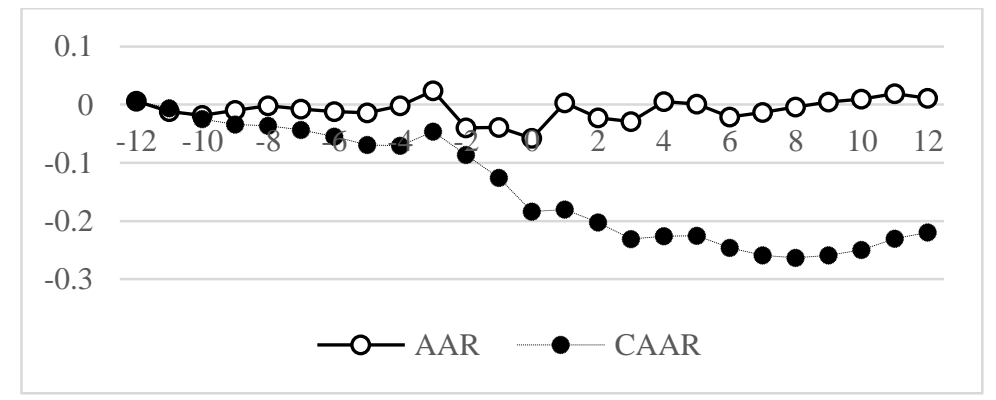

Figure 3. AAR and CAAR around government interventions during currency crises

The results for the average CARs are presented in Figure 3. It shows the patterns of the CARs which confirm the negative impact of government intervention on stock returns during currency crises. There are also negative abnormal returns before the government intervention, as showed that there is a huge drop of abnormal return from 2.4 percent in the month $(\mathrm{t}=-3)$ to -5.8 percent in the event month $(\mathrm{t}=\mathrm{O})$. It shows that the stock markets may anticipate intervention and the negative CARs before the intervention event reflects that expectation. One month after the intervention event, the abnormal returns rise to 0.3 percent, but then it falls and fluctuates again.

The calculation of the significance of CARs by t-test from Stata is similar with the result of calculating it's significant by dividing the CARs with the standard error. After calculating the significance by dividing CARs with the standard error, this study finds that the CARs are significantly different from zero at 10 percent level in a month before the event. However, the CARs of the month $(\mathrm{t}=\mathrm{O})$ and the months after that are significant at 1 percent level. As presented in Appendix C, it shows that there are significant negative abnormal returns after the interventions during currency crises.

\section{DISCUSSION}

Stock market reactions to government interventions vary immensely across countries. The determinant factors are the timing and a number of International reserves the countries can use (Glen, 2002; Hsu \& Fiesty, 2016; Madura, 2013; Patro et al., 2014). The abnormal returns around government intervention in Asian currency crises in this study show that the government intervention significantly makes negative abnormal returns. However, the stock markets do not 
anticipate the government intervention and the intervention is taken while the abnormal return is normal.

This study shows that there are significant negative abnormal returns after the interventions during crises and this study does not find the positive returns following the government interventions during crises. Similarly, Glen (2002) and Patro, Wald, and Wu (2014) also find the negative returns following devaluations. The bottom line here is that the market forces might be too strong in currency crises periods and the governments could not offset it. However, this empirical result also shows that intervention is an important event and has essential information for investors during currency crises.

\section{LIMITATION AND FUTURE RESEARCH}

This research finds that the government interventions do not effectively impact exchange rate, stock price, and stock market return during the crises periods. In the Asian crises and crises of each country, there are significant negative abnormal returns after the government intervention. The reason for the negative abnormal returns is might because the market forces were too strong and the government could not handle those.

In currency crises periods, the government intervention does not always effectively impact the exchange rate and stock market return. It means the government's decision to intervene in the foreign exchange market is risky. The future study can analyze the condition before and after government intervention only in one or two countries. In hence, the research will be more specific and get a comprehensive understanding of the government intervention impact on the stock market.

\section{REFERENCES}

Adler, G., Lisack, N., \& Mano, R. (2015). Unveiling the Effects of Foreign Exchange Intervention: A Panel Approach. International Monetary Fund.

Aguilar, J., \& Nydahl, S. (2000). Central bank intervention and exchange rates: the case of Sweden. Journal of International Financial Markets, Institutions and Money, 10(3-4), 303-322. doi: 10.1016/S1042-4431(oo)00041-X

Bank for International Settlements. (2005). Foreign exchange market intervention in emerging markets: motives, techniques, and implications. Basel.

Behera, H., Narasimhan, V., \& Murty, K. N. (2008). Relationship between exchange rate volatility and central bank intervention: An empirical analysis for India. South Asia Economic Journal, 9(1), 69-84. doi: 10.1177/139156140700900103

Beine, M., Bénassy-Quéré, A., \& Lecourt, C. (2002). Central bank intervention and foreign exchange rates: new evidence from FIGARCH estimations. Journal of International Money and Finance, 21(1), 115-144. doi: 10.1016/So261-56o6(01)00040-7

Beine, M., \& Lecourt, C. (2004). Reported and secret interventions in the foreign exchange markets. Finance Research Letters, 1(4), 215-225. doi: 10.1016/j.frl.2004.08.002

Dominguez, K. M. (1998). Central bank intervention and exchange rate volatility1. Journal of International Money and Finance, 17(1), 161-190. 
Égert, B., \& Kočenda, E. (2014). The impact of macro news and central bank communication on emerging European forex markets. Economic Systems, 38(1), 73-88. doi: 10.1016/j.jimonfin.2014.12.010

Erler, A., Bauer, C., \& Herz, B. (2015). To intervene, or not to intervene: Monetary policy and the costs of currency crises. Journal of International Money and Finance, 51, 432-456.

Fama, E. F., \& MacBeth, J. D. (1973). Risk, return, and equilibrium: Empirical tests. Journal of Political Economy, 81(3), 607-636.

Glen, J. (2002). Devaluations and emerging stock market returns. Emerging Markets Review, 3(4), 409-428. doi: 10.1016/S1566-0141(02)0oo44-4

Hartmann, D., \& Pierdzioch, C. (2007). Stock returns, exchange rate movements and central bank interventions. Applied Financial Economics Letters, 3(3), 191-195. doi: 10.1080/17446540600972435

Hsu, Ai-Chi; Fiesty, U. (2016). Central Bank Intervention and The Stock Market Response. KKG Publications, 2(5).

Humpage, O. F. (1988). Intervention and the Dollar's Decline. Economic Review, 24(2), 2-16.

Inoue, T. (2015). Central Bank Intervention And Exchange Rate Behavior: Empirical Evidence For India. The Singapore Economic Review, 6o(2), 1550016.

Laeven, L., \& Valencia, F. (2018). Systemic Banking Crises Revisited. International Monetary Fund.

MacKinlay, A. C. (1997). Event studies in economics and finance. Journal of Economic Literature, 35(1), 13-39.

Madura, J. (2002). Financial markets and institusions (6th ed.). Mason, OH: South-Western Cengage Learning.

Madura, J. (2013). International corporate finance (11th ed.). Mason, OH: South-Western Cengage Learning.

Madura, J. (2014). International financial management (12th ed.). Mason, OH: South-Western Cengage Learning.

Markus. (2003). Value relevance of analysts' earnings forecasts. Equity Strategy Research.

Mishkin, F. S. (2013). The economics of money, banking, and financial markets (10th ed.). Boston: Pearson education.

Neely, C. J. (2005). An analysis of recent studies of the effect of foreign exchange intervention. Working Paper Series. The Federal Reserve Bank of St. Louis.

Patro, D. K., Wald, J. K., \& Wu, Y. (2014). Currency devaluation and stock market response: An empirical analysis. Journal of International Money and Finance, 40, 79-94. doi:10.1016/j.jimonfin.2013.09.005

Pattanaik, S., \& Sahoo, S. (2003). The effectiveness of intervention in India: an empirical assessment. Reserve Bank of India Occasional Papers, 22.

Pennathur, A., Smith, D., \& Subrahmanyam, V. (2014). The stock market impact of government interventions on financial services industry groups: Evidence from the 2007-2009 crisis. Journal of Economics and Business, 71, 22-44.

Pontines, V., \& Rajan, R. S. (2011). Foreign exchange market intervention and reserve accumulation in emerging Asia: Is there evidence of fear of appreciation? Economics Letters, 111(3), 252-255. doi: 10.1016/j.econlet.2011.01.022

Reboredo, J. C., Rivera-Castro, M. A., \& Ugolini, A. (2016). Downside and upside risk spillovers between exchange rates and stock prices. Journal of Banking \& Finance, 62, 76-96. doi:10.1016/j.jbankfin.2015.10.011

Reinhart, C. M., \& Rogoff, K. S. (2011). From financial crash to debt crisis. American Economic Review, 101(5), 1676-1706. doi: 10.3386/w15795

Wong, H. T. (2014). Exchange rate and central bank intervention. Journal of Global Economics, 2(1), 1-4. doi: 10.4172/2375-4389.1000e104 
Appendix A. Government Intervention Events during Asian Crises (July 1997-1998)

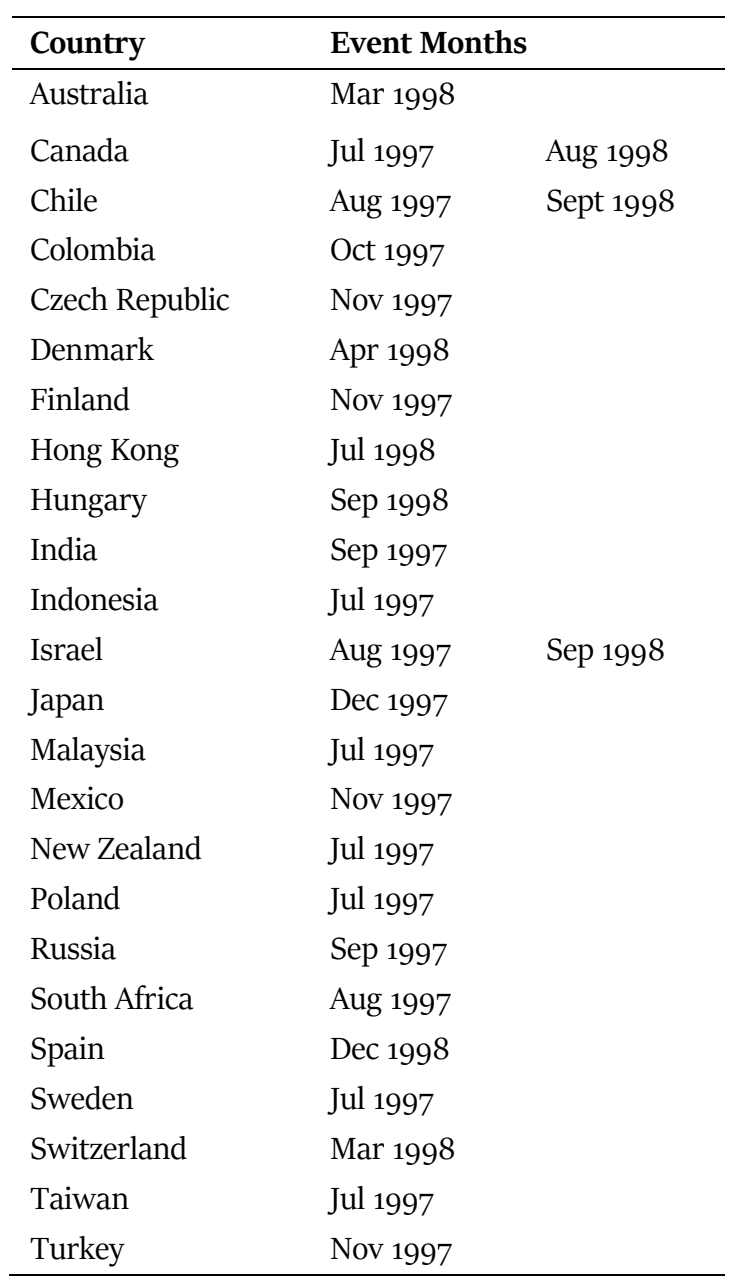


Appendix B. Government events during currency crises period of each country

\begin{tabular}{|c|c|c|c|c|c|c|}
\hline Country & Event Mon & & & & & \\
\hline Argentina & Mar 2002 & Jun 2013 & & & & \\
\hline Australia & May 2000 & & & & & \\
\hline Chile & Oct 2008 & & & & & \\
\hline Colombia & Jun 1995 & Oct 1997 & Jul 1999 & & & \\
\hline Denmark & Nov 2010 & & & & & \\
\hline France & Feb 2005 & & & & & \\
\hline Hungary & Apr 1997 & Mar 1999 & Jun 2008 & & & \\
\hline India & Jun 2008 & & & & & \\
\hline Indonesia & Mar 1997 & Jun 1998 & Sep 2000 & Jan 2008 & & \\
\hline Malaysia & Jul 1997 & & & & & \\
\hline Mexico & Nov 1995 & Jun 1998 & Oct 2008 & & & \\
\hline New Zealand & Jan 1997 & Jul 2008 & & & & \\
\hline Poland & Apr 1996 & Jul 1997 & Mar 1999 & Sep 2008 & & \\
\hline Portugal & Dec 2005 & & & & & \\
\hline Russia & Jan 1998 & Aug 1999 & Oct 2008 & Dec 2014 & & \\
\hline South Africa & Feb 1996 & Jan 1998 & & & & \\
\hline Spain & Mar 2005 & & & & & \\
\hline Switzerland & Sep 1999 & & & & & \\
\hline Turkey & Jan 1994 & May 1995 & Dec 1996 & Aug 1998 & Nov 2000 & Oct 2008 \\
\hline United Kingdom & Mar 2008 & & & & & \\
\hline United States & Feb 2002 & & & & & \\
\hline
\end{tabular}




\section{UTAMI AND HSU}

Appendix C. Cumulative abnormal returns (CARs) around government intervention

\begin{tabular}{|c|c|c|c|c|c|c|c|c|c|c|c|c|c|c|c|c|}
\hline \multicolumn{17}{|c|}{\begin{tabular}{l|l|l} 
PANEL A: ASIAN CURRENCY CRISES \\
\end{tabular}} \\
\hline & & $(-5,-1)$ & $(-2,-1)$ & $-12,+12$ & $(-9,+9)$ & $(-8,+8)$ & $(-6,+6)$ & $(-5,+5)$ & $(-4,+4)$ & $(-3,+3)$ & $(-2,+2)$ & $(-1,+1)$ & $(-1,+3)$ & $(-1,+12)$ & $(0,+3)$ & $(0,+12)$ \\
\hline Asian crises & 27 & -0.07 & -0.02 & $-0.47 * * \bullet$ & $-0.33 * \cdots$ & $-0.26^{* * *}$ & $-0.30 * \cdots$ & $-0.31 \bullet *$ & $-0.25 * * *$ & $-0.16 * * *$ & $-0.11 * *$ & $-0.08 * * *$ & $-0.14 * *$ & $-0.43 * * *$ & $-0.13^{* * *}$ & $-0.42 \cdots$ \\
\hline t-statistics & 27 & -1.53 & -0.6 & $-3.43 * * *$ & $-3.60 * * *$ & $-3.24 * * *$ & $-3.55 * * *$ & $-3.25 * * *$ & $-3.53 * * *$ & $-2.94 * \cdots$ & $-2.35 * *$ & $-2.65 * * *$ & $-3.01 * *$ & $-3.52 * * *$ & $-2.97 * * *$ & $-3.44 * *$ \\
\hline z-statistics & 27 & 0.03 & 0.56 & $-3.27 * * *$ & $-2.89 * *$ & $-2.12 * *$ & $-4.04 * \cdots$ & $-4.04 * \cdots$ & $-3.66 * *$ & $-2.89 * \cdots$ & $-1.73^{*}$ & $-2.50 * *$ & $-2.50 * *$ & $-3.66 * * *$ & $-3.66 * * *$ & $-3.66 * *$ \\
\hline Australia & 1 & -0.16 & -0.09 & -0.4 & -0.35 & -0.24 & -0.13 & -0.24 & -0.21 & -0.21 & -0.22 & -0.14 & -0.24 & -0.19 & -0.15 & -0.11 \\
\hline Canada & 2 & -0.1 & -0.08 & -0.19 & -0.13 & -0.14 & -0.16 & -0.18 & -0.17 & -0.11 & -0.12 & $-0.05^{* * *}$ & -0.08 & $-0.17^{*+*}$ & -0.02 & $-0.11 * * *$ \\
\hline Chile & 2 & -0.1 & -0.03 & $-0.31 * * *$ & -0.13 & -0.04 & -0.1 & -0.22 & -0.19 & -0.1 & 0.01 & -0.08 & -0.11 & -0.17 & -0.04 & -0.1 \\
\hline Colombia & 1 & -0.19 & 0.13 & -0.68 & -0.52 & -0.37 & -0.54 & -0.67 & -0.27 & 0.07 & 0.25 & 0.04 & -0.01 & -0.81 & -0.03 & -0.84 \\
\hline Czech Republic & 1 & -0.02 & 0 & -0.66 & -0.58 & -0.56 & -0.37 & -0.22 & -0.1 & -0.11 & -0.25 & -0.13 & -0.22 & -0.35 & -0.22 & -0.36 \\
\hline Denmark & 1 & 0.08 & -0.01 & -0.38 & -0.2 & -0.17 & -0.08 & -0.1 & -0.11 & -0.05 & -0.07 & 0.01 & -0.03 & -0.39 & -0.07 & -0.43 \\
\hline Finland & 1 & 0.21 & 0.15 & 0.92 & 0.61 & 0.69 & 0.54 & 0.45 & 0.31 & 0.23 & 0.05 & -0.07 & 0.16 & 0.57 & 0.08 & 0.49 \\
\hline Hong Kong & 1 & -0.28 & -0.24 & -0.43 & -0.31 & -0.16 & -0.3 & -0.03 & -0.07 & -0.02 & -0.16 & -0.14 & 0.2 & 0.23 & 0.32 & 0.35 \\
\hline Hungary & 1 & -0.47 & -0.2 & -1.44 & -1.06 & -0.99 & -0.9 & -0.89 & -0.65 & -0.43 & -0.35 & -0.49 & -0.32 & -0.96 & -0.14 & -0.78 \\
\hline India & 1 & -0.07 & 0.01 & -0.03 & -0.11 & 0 & -0.06 & -0.23 & -0.2 & 0.09 & -0.04 & -0.01 & 0 & -0.06 & 0.02 & -0.04 \\
\hline Indonesia & 1 & -0.25 & -0.07 & -1.65 & -1.5 & -1.19 & -1.32 & -1.97 & -1.31 & -0.99 & -0.66 & -0.46 & -0.89 & -1.54 & -0.78 & -1.42 \\
\hline Israel & 2 & $-0.06 * * *$ & -0.02 & -0.15 & -0.12 & -0.14 & -0.2 & -0.16 & -0.11 & -0.21 & -0.11 & -0.1 & -0.08 & -0.09 & -0.1 & -0.11 \\
\hline Japan & 1 & -0.16 & -0.08 & -0.29 & -0.22 & -0.26 & -0.36 & -0.32 & -0.31 & -0.24 & -0.12 & 0 & -0.15 & -0.1 & -0.11 & -0.06 \\
\hline Malaysia & 1 & -0.26 & -0.18 & -1.48 & -0.99 & -0.78 & -1.29 & -1.18 & -1.12 & -0.92 & -0.65 & -0.3 & -0.7 & -1.34 & -0.66 & -1.3 \\
\hline Mexico & 1 & 0.14 & -0.01 & -0.38 & -0.5 & -0.36 & -0.25 & -0.06 & -0.08 & -0.17 & -0.14 & -0.05 & -0.28 & -0.59 & -0.23 & -0.54 \\
\hline New Zealand & 1 & -0.12 & -0.08 & -0.33 & -0.31 & -0.33 & -0.19 & -0.22 & -0.07 & -0.01 & -0.06 & -0.01 & 0.04 & -0.37 & 0.03 & -0.38 \\
\hline Poland & 1 & -0.37 & -0.33 & -0.56 & -0.62 & -0.44 & -0.57 & -0.6 & -0.62 & -0.32 & -0.3 & -0.13 & -0.11 & -0.36 & -0.03 & -0.28 \\
\hline Russia & 1 & -0.04 & 0.1 & -2.68 & -1.37 & -1.08 & -1.06 & -0.87 & -0.7 & -0.35 & -0.3 & -0.14 & -0.43 & -2.69 & -0.43 & -2.69 \\
\hline South Africa & 1 & 0.07 & 0.06 & -0.47 & 0.09 & 0.2 & -0.02 & -0.26 & -0.23 & -0.14 & $\begin{array}{ll}-0.04 \\
\end{array}$ & -0.08 & -0.22 & -0.59 & -0.23 & -0.6 \\
\hline Spain & 1 & -0.09 & 0.06 & -0.16 & -0.33 & -0.41 & -0.35 & -0.25 & -0.3 & -0.17 & 0.01 & -0.01 & -0.11 & -0.23 & -0.13 & -0.25 \\
\hline Sweden & 1 & -0.16 & -0.15 & -0.14 & -0.16 & -0.18 & -0.12 & -0.13 & -0.06 & -0.15 & -0.07 & -0.06 & -0.06 & -0.12 & 0.01 & -0.05 \\
\hline Switzerland & 1 & 0.16 & 0.09 & 0.21 & 0.19 & 0.16 & 0.16 & 0.15 & 0.24 & 0.14 & 0.11 & 0.03 & 0.06 & -0.04 & 0 & -0.1 \\
\hline Taiwan & 1 & 0.1 & 0.03 & -0.56 & -0.28 & -0.2 & -0.32 & -0.27 & -0.3 & -0.23 & $\begin{array}{l}-0.04 \\
\end{array}$ & 0.12 & -0.19 & -0.55 & -0.27 & -0.64 \\
\hline Turkey & 1 & 0.65 & 0.56 & 0.28 & 0.26 & 0.27 & 0.4 & 0.61 & 0.27 & 0.36 & 0.51 & 0.27 & 0.2 & -0.28 & -0.16 & $\begin{array}{l}-0.64 \\
\end{array}$ \\
\hline
\end{tabular}




\begin{tabular}{|c|c|c|c|c|c|c|c|c|c|c|c|c|c|c|c|c|}
\hline \multicolumn{17}{|c|}{ PANEL B: CURRENCY CRISES IN EACH COUNTRY } \\
\hline & $\mathrm{N}$ & $(-5,-1)$ & $(-2,-1)$ & $(-12,+12)$ & $(-9,+9)$ & $(-8,+8)$ & $(-6,+6)$ & $(-5,+5)$ & $(-4,+4)$ & $(-3,+3)$ & $(-2,+2)$ & $(-1,+1)$ & $(-1,+3)$ & $(-1,+12)$ & $(0,+3)$ & $(0,+12)$ \\
\hline $\begin{array}{l}\text { Currency } \\
\text { Crises }\end{array}$ & 41 & -0.04 & -0.06 & -0.12 & -0.21 & $-0.21 \bullet$ & -0.15 & -0.12 & -0.11 & $-0.13 \bullet$ & $-0.11 \bullet$ & $-0.08 * *$ & $-0.12 * *$ & -0.07 & -0.08 & -0.04 \\
\hline t-statistics & 41 & -0.97 & -1.9 & -0.76 & -1.56 & $-1.74^{\bullet}$ & -1.44 & -1.24 & -1.31 & $-1.73 \bullet$ & $-1.93 *$ & $-2.07 * *$ & $-2.08 * *$ & -0.54 & -1.51 & -0.28 \\
\hline z-stat & 41 & 0.16 & 0.008 & -0.47 & $-1.72 *$ & $-2.66 * * *$ & $-2.34 * *$ & $-1.72^{*}$ & $-2.34 * *$ & $-2.34 * *$ & $-1.72^{*}$ & $-2.03 * *$ & $-2.97 * * *$ & -1.09 & $-2.34^{* *}$ & -0.47 \\
\hline Argentina & 2 & -0.04 & -0.31 & 0.13 & -0.05 & -0.3 & -0.14 & -0.35 & -0.07 & -0.23 & -0.92 & -0.54 & -0.68 & 0.18 & -0.59 & 0.27 \\
\hline Australia & 1 & -0.07 & -0.06 & -0.01 & 0 & -0.01 & -0.04 & -0.02 & -0.03 & -0.02 & 0 & 0.02 & 0.05 & 0.18 & 0.07 & 0.2 \\
\hline Chile & 1 & -0.22 & -0.12 & -0.17 & 0.01 & 0.04 & -0.13 & -0.07 & -0.02 & -0.09 & -0.19 & -0.06 & -0.03 & -0.07 & 0.04 & 0 \\
\hline Colombia & 3 & -0.17 & -0.08 & -0.87 & -0.72 & -0.61 & -1.12 & -1.14 & -0.98 & -0.94 & -0.78 & -0.14 & -0.27 & $-0.70 * * *$ & -0.19 & -1.96 \\
\hline Denmark & 1 & 0 & -0.01 & -0.37 & -0.23 & -0.19 & -0.14 & -0.07 & -0.06 & -0.17 & -0.08 & -0.06 & -0.11 & -0.31 & -0.1 & -0.3 \\
\hline France & 1 & -0.02 & -0.03 & -0.3 & -0.24 & -0.19 & -0.1 & -0.08 & -0.09 & -0.07 & -0.04 & -0.04 & -0.08 & -0.17 & -0.04 & -0.14 \\
\hline Hungary & 3 & $0.10^{* * *}$ & $-0.17^{* * * *}$ & -0.09 & -0.18 & -0.13 & -0.02 & 0.18 & 0.18 & 0.03 & -0.09 & -0.12 & -0.08 & -0.06 & 0.07 & 0.1 \\
\hline India & 1 & -0.21 & -0.09 & 0.54 & 0.35 & 0.23 & -0.13 & 0.01 & -0.28 & -0.23 & -0.04 & -0.03 & -0.12 & 0.32 & -0.02 & 0.42 \\
\hline Indonesia & 4 & -0.01 & -0.05 & 0.14 & -0.43 & -0.43 & 0.1 & 0.27 & 0.15 & -0.15 & 0.01 & -0.02 & -0.13 & 0.66 & -0.05 & 0.75 \\
\hline Malaysia & 1 & -0.26 & -0.18 & -1.48 & -0.99 & -0.78 & -1.29 & -1.18 & -1.12 & -0.92 & -0.65 & -0.3 & -0.7 & -1.34 & -0.66 & -1.3 \\
\hline Mexico & 3 & $-0.19^{* * *}$ & $-0.13 * * *$ & -0.41 & -0.24 & $-0.26 * *$ & -0.19 & $-0.23 * *$ & $-0.19 * * *$ & $-0.19 * * *$ & -0.17 & $-0.15^{* * * *}$ & $-0.20^{* * * *}$ & -0.17 & -0.07 & -0.05 \\
\hline New Zealand & 2 & -0.12 & -0.1 & -0.5 & -0.47 & -0.41 & -0.42 & -0.39 & -0.43 & -0.28 & $-0.21^{*}$ & $-0.13^{*}$ & -0.22 & $-0.34 * * *$ & -0.17 & $-0.29 * * *$ \\
\hline Poland & 4 & -0.06 & -0.03 & 0.24 & 0.02 & 0.06 & 0.02 & 0.04 & 0.06 & 0.18 & 0.08 & -0.05 & 0.15 & 0.26 & 0.16 & 0.27 \\
\hline Portugal & 1 & -0.07 & -0.05 & -0.13 & -0.11 & -0.09 & -0.06 & 0.05 & 0.1 & 0.07 & 0.06 & 0.01 & 0.08 & 0.08 & 0.14 & 0.14 \\
\hline Russia & 4 & 0.02 & -0.13 & 0.36 & 0.09 & -0.06 & 0.22 & 0.05 & -0.22 & -0.21 & -0.22 & $-0.22^{*}$ & -0.18 & -0.1 & -0.14 & -0.06 \\
\hline South Africa & 2 & -0.12 & -0.07 & -0.31 & -0.44 & $-0.46 * *$ & -0.3 & -0.24 & -0.08 & -0.05 & -0.08 & -0.02 & 0.02 & -0.29 & 0.02 & -0.29 \\
\hline Spain & 1 & 0.07 & -0.05 & -0.34 & -0.22 & -0.2 & -0.07 & -0.07 & -0.12 & -0.13 & -0.13 & -0.04 & -0.12 & -0.21 & -0.13 & -0.22 \\
\hline Switzerland & 1 & -0.13 & -0.01 & -0.74 & -0.66 & -0.59 & -0.51 & -0.37 & -0.3 & -0.21 & -0.13 & 0 & -0.1 & -0.29 & -0.15 & -0.34 \\
\hline Turkey & 6 & 0.13 & 0.1 & 0.24 & -0.1 & -0.14 & -0.15 & -0.15 & -0.04 & -0.08 & -0.01 & 0.05 & -0.09 & -0.06 & -0.17 & -0.13 \\
\hline $\begin{array}{l}\text { United } \\
\text { Kingdom }\end{array}$ & 1 & -0.06 & -0.03 & -0.35 & -0.35 & -0.33 & -0.2 & -0.14 & -0.11 & -0.12 & -0.05 & 0.01 & -0.04 & -0.22 & -0.06 & -0.24 \\
\hline United States & 1 & 0.02 & -0.01 & 0.02 & 0.04 & 0.05 & -0.01 & -0.11 & -0.08 & -0.07 & -0.08 & -0.03 & -0.05 & -0.02 & -0.05 & -0.01 \\
\hline
\end{tabular}

The symbols * ${ }^{* *}$, and ${ }^{* * *}$ represent statistical significance using a 2-tail test at the 10, 5, and 1 percent levels, respectively. 